\title{
Oxidative Precipitation of Manganese from Acid Mine Drainage by Potassium Permanganate
}

\author{
Regeane M. Freitas, Thomaz A. G. Perilli, and Ana Claudia Q. Ladeira \\ Centre for Development of Nuclear Technology (CDTN), Av, Antônio Carlos 6627, Campus UFMG, \\ 31270901 Belo Horizonte, MG, Brazil \\ Correspondence should be addressed to Regeane M. Freitas; rmdf2@cam.ac.uk
}

Received 8 May 2013; Accepted 4 October 2013

Academic Editor: Eva Pocurull

Copyright (C) 2013 Regeane M. Freitas et al. This is an open access article distributed under the Creative Commons Attribution License, which permits unrestricted use, distribution, and reproduction in any medium, provided the original work is properly cited.

\begin{abstract}
Although oxidative precipitation by potassium permanganate is a widely recognised process for manganese removal, research dealing with highly contaminated acid mine drainage (AMD) has yet to be performed. The present study investigated the efficiency of $\mathrm{KMnO}_{4}$ in removing manganese from AMD effluents. Samples of AMD that originated from inactive uranium mine in Brazil were chemically characterised and treated by $\mathrm{KMnO}_{4}$ at $\mathrm{pH}$ 3.0, 5.0, and 7.0. Analyses by Raman spectroscopy and geochemical modelling using PHREEQC code were employed to assess solid phases. Results indicated that the manganese was rapidly oxidised by $\mathrm{KMnO}_{4}$ in a process enhanced at higher $\mathrm{pH}$. The greatest removal, that is, $99 \%$, occurred at $\mathrm{pH} 7.0$, when treated waters presented manganese levels as low as $1.0 \mathrm{mg} / \mathrm{L}$, the limit established by the Brazilian legislation. Birnessite $\left(\mathrm{MnO}_{2}\right)$, hausmannite $\left(\mathrm{Mn}_{3} \mathrm{O}_{4}\right)$, and manganite $(\mathrm{MnOOH})$ were detected by Raman spectroscopy. These phases were consistently identified by the geochemical model, which also predicted phases containing iron, uranium, manganese, and aluminium during the correction of the $\mathrm{pH}$ as well as bixbyite $\left(\mathrm{Mn}_{2} \mathrm{O}_{3}\right)$, nsutite $\left(\mathrm{MnO}_{2}\right)$, pyrolusite $\left(\mathrm{MnO}_{2}\right)$, and fluorite $\left(\mathrm{CaF}_{2}\right)$ following the $\mathrm{KMnO}_{4}$ addition.
\end{abstract}

\section{Introduction}

The oxidation of sulphide minerals exposed to oxygen and water produces acid effluents commonly referred to as acid mine drainage (AMD), described in detail elsewhere [1]. Although the generation of acid drainage is a natural phenomenon, mining activities can dramatically increase its production due to the large amounts of material usually exposed. In addition to its main characteristics (e.g., high acidity and sulphate levels), AMD features extensive chemical diversity, including metals such as iron, aluminium, and manganese in elevated concentrations [2]. These effluents are potentially hazardous to the environment. However, technologies available to deal with AMD are either unsuitable or costly [3]. Furthermore, practices are fairly exclusive and varying significantly from one site to another, which characterises several problems in terms of the implementation of available methodologies.

In Brazil, for instance, as a consequence of high contents of manganese in the soil, the concentration of this metal in
AMD can be up to 150 times the limit of $1.0 \mathrm{mg} / \mathrm{L}$ recognised by CONAMA Resolution 430 (Brazilian legislation) [4]. However, the majority of studies performed so far have addressed the removal of manganese from waters with low contamination such as drinking water (e.g., [5-8]). The management of AMD with exceptionally high concentration of manganese sets a totally new and challenging scenario within the remediation technologies and research on this topic is still necessary.

Overall, challenges in removing manganese from AMD arise from two main factors. First, the conditions of effluents, that is, $\mathrm{pH}$ and $\mathrm{Eh}$, are unfavourable for manganese precipitation; second, AMD effluents are very complex in terms of chemical composition. Currently, the most widely employed treatment consists of active systems using chemical-neutralising agents such as sodium hydroxide and limestone to precipitate manganese $[1,9]$. However, the need for high $\mathrm{pH}$ condition (i.e., $\mathrm{pH}>11$ ) raises expenses due to chemical consumption and yet leads to unsatisfactory treated waters considering the recommended $\mathrm{pH}$ range between 
5 and 9 (CONAMA Resolution 430) [4]. Furthermore, this process also generates large amounts of bulky sludge, which requires further treatment and appropriate disposal $[1,10]$.

In this context, oxidative precipitation seems to be a more suitable alternative for removing manganese from AMD [11]. Manganese reacts with an oxidant agent generating a colloidal precipitate, which is then separated by filtration or sedimentation [12]. Several oxidant agents such as air [13], chlorine [14], ozone [15], sulphur dioxide, and oxygen [16] were evaluated in studies that focused mainly on slightly contaminated effluents. In general, potassium permanganate $\left(\mathrm{KMnO}_{4}\right)$ stands out with the advantage of removing other contaminants such as iron and organic compounds responsible for taste and odour [17]. Therefore, there is great interest in establishing optimised operating conditions that enable the use of $\mathrm{KMnO}_{4}$ for remediating highly contaminated AMD.

The assessment of reaction rates as well as solid phases formed during remediation procedures provide valuable information in designing and optimising efficient treatment methods. Van Benschoten et al. [12] published an extensive work on the kinetics of manganese oxidation by $\mathrm{KMnO}_{4}$. According to these authors oxidation rates depend on concentrations of oxidant, hydroxyl ions, manganese oxides and free manganese. Other factors such as coprecipitation, adsorption [18], and the autocatalytic effect of precipitates [19] were also reported to affect the removal of manganese and other contaminants, which indicates the importance of investigating the solid phases produced.

Geological models are particularly appropriate to assess solid phases in aqueous systems such as AMD. For instance, the software PHREEQC [20] has proved extremely useful in providing conceptual models focusing on water treatment and environmental remediation technologies [10, 21-23]. Based on ionic associations, the program, amongst other options, allows saturation-index calculations and chemical speciation. PHREEQC employs a solubility approach to identify thermodynamically possible solid phases, which may potentially support the conception and management of efficient treatment systems for AMD.

In this study the oxidative precipitation of manganese by $\mathrm{KMnO}_{4}$ was investigated with the objective of achieving an effective treatment method for highly contaminated AMD. Experiments were divided into two parts: the first one was performed with $\mathrm{MnSO}_{4}$ solutions prepared in the laboratory and the second with AMD samples collected in an inactive uranium mine at the Plateau of Poços de Caldas, southeast of Brazil. Processes were conducted at $\mathrm{pH}$ 3.0, 5.0, and 7.0. Precipitates were characterised by spectroscopy techniques and electron microprobe. In addition, a geochemical model using the PHREEQC software was developed to predict solid phases possibly formed at each stage of the remediation process.

\section{Methodology}

2.1. Liquid Samples. Laboratory solutions were prepared by diluting $0.31 \mathrm{~g}$ of $\mathrm{MnSO}_{4} \cdot \mathrm{H}_{2} \mathrm{O}$ (Vetec, Brazil) in $1.0 \mathrm{~L}$ of deionized water. Acid mine drainage samples, identified as A1 and $\mathrm{A} 2$, were collected in two different water dams located in one former and inactive uranium mine. Effluents were chemically characterised and results are shown in Table 1.

2.2. Bench Experiments. Experiments were carried out in glass beakers with $200 \mathrm{~mL}$ of liquid samples. Initially, under stirring and at room temperature $\left(25^{\circ} \mathrm{C} \pm 0.5\right)$, the $\mathrm{pH}$ was adjusted by adding sodium hydroxide or sulphuric acid. One aliquot was taken to determine the initial concentration of manganese which ranged from 90 to $105 \mathrm{mg} / \mathrm{L}$. Afterwards, $\mathrm{KMnO}_{4} 4 \%(\mathrm{w} / \mathrm{v})$ was added to the solutions based on predetermined ratios: $1.63 \mathrm{mg} \mathrm{KMnO}_{4} / \mathrm{mg} \mathrm{Mn}$ for experiments at $\mathrm{pH} 3.0$ and $1.54 \mathrm{mg} \mathrm{KMnO}_{4} / \mathrm{mg} \mathrm{Mn}$ for $\mathrm{pH} 5.0$ and 7.0. Samples were collected at pre-established time and filtered in $0.45 \mu \mathrm{m}$ membranes. Ratio and reaction time values were determined in a previous study based on statistic factorial design considering four parameters: concentration of the oxidant agent, reaction time, stoichiometry, and $\mathrm{pH}$. Sulphuric acid solution and sodium bisulphite 5\% (w/v) were added to the filtrate as quenching agents. Manganese, aluminium, calcium, iron, and zinc, were determined by atomic absorption spectrophotometry (VARIAN, model AA240FS). Uranium was assessed by X-ray fluorescence spectrophotometry (SHIMADZU model EDX-720).

2.3. Solid Samples. Solid samples at $\mathrm{pH} 7.0$ were dried at room temperature and then analysed by Raman Spectroscopy (JOBIN-YVON, LABRAM model HR-800), Scanning Electron Microscope (JEOL JSM, model 840A), and Electron Probe Microanalysis coupled to EDS detector (JEOL JXA, model 8900 RT).

2.4. PHREEQC Modelling. The oxidative precipitation of manganese was modelled using the geochemical program PHREEQC-Version 2 [20]. The consistent thermodynamic database WATEQ4F [24] was used to construct forward models focusing on the assessment of saturation index (SI). The developed speciation-solubility model comprised defined amounts of the $\mathrm{KMnO}_{4} 4 \%(\mathrm{w} / \mathrm{v})$ allowed to react reversibly with aqueous solutions simulating the compositions of $\mathrm{MnSO}_{4}$ and $\mathrm{AMD}$ samples. Based on the conditions of the system, each phase precipitated when SI $>0$ was reached or dissolved completely when SI $<0$ to achieve the equilibrium, SI $=0$. It is worth saying that the condition of equilibrium, SI = 0 , does not guarantee that the solid physical state will prevail, but taking into consideration that AMD effluents are highly concentrated, the precipitation is relatively favourable. The simulation was conducted in three steps: (i) simulation of initial $\mathrm{KMnO}_{4}, \mathrm{MnSO}_{4}$ and $\mathrm{AMD}$ solutions, (ii) addition of potassium permanganate, and (iii) equilibrium between solid phases and generating solution. In addition to the phases identified by Raman spectroscopy, all thermodynamically possible phases were also considered.

\section{Results and Discussion}

3.1. Oxidation Rates. Data for $\mathrm{MnSO}_{4}$ solutions prepared in laboratory including different $\mathrm{pH}$ values are presented 
TABLE 1: Chemical characterization of acid mine drainage solutions.

\begin{tabular}{lccc}
\hline & A1 & A2 & Maximum limits for effluents discharge \\
\hline $\mathrm{Mn}$ & 102.6 & 92.3 & 1.0 \\
$\mathrm{Fe}$ & 2.8 & 0.8 & 15 \\
$\mathrm{Zn}$ & 3.2 & 2.8 & 5 \\
$\mathrm{Ni}$ & 0.1 & 0.2 & 2 \\
$\mathrm{Co}$ & 0.1 & 0.02 & $*$ \\
$\mathrm{U}$ & 9.5 & 9.5 & $*$ \\
$\mathrm{Ca}$ & 251.9 & 142.2 & $*$ \\
$\mathrm{Al}$ & 194.8 & 176.2 & $*$ \\
$\mathrm{~Pb}$ & 0.1 & $<0.05$ & 0.5 \\
$\mathrm{~F}^{-}$ & 65.2 & 79.4 & 10 \\
$\mathrm{SO}_{4}{ }^{2-}$ & 1818 & 1230 & $*$ \\
$\mathrm{TOC}^{-}$ & 1.5 & 2.4 & $*$ \\
$\mathrm{pH}^{-5}$ & 3.1 & 3.6 & 5.0 to 9.0 \\
\hline
\end{tabular}

Concentrations of all components are in mg/L. * CONAMA Resolution 430 has no limits for these components [4].

in Figure 1, where the region of low concentrations was highlighted. Laboratory solutions were firstly employed to evaluate oxidation rates of manganese without the interference of other contaminants. The equilibrium was reached within approximately $20 \mathrm{~min}$ of reaction, when manganese was almost completely removed. Comparatively, performances of experiments conducted at $\mathrm{pH} 5.0$ and 7.0 were similar, with manganese contents being practically constant and below $0.1 \mathrm{mg} / \mathrm{L}$ after $10 \mathrm{~min}$ of reaction. On the other hand, at $\mathrm{pH}$ 3.0 the lowest manganese concentration was approximately $0.3 \mathrm{mg} / \mathrm{L}$ after $60 \mathrm{~min}$ of reaction. Nevertheless, all processes accomplished final concentrations of manganese lower than $1.0 \mathrm{mg} / \mathrm{L}$ [4], demonstrating that $\mathrm{KMnO}_{4}$ doses and $\mathrm{pH}$ conditions chosen were appropriate.

As expected, owing to the reduced availability of reactants, oxidation rates initially high in all trials decreased over time. Overall, reactions at $\mathrm{pH} 5.0$ and 7.0 were more efficient compared to $\mathrm{pH}$ 3.0. These results are consistent with those given by Van Benschoten et al. [12] reporting a trend of higher oxidation rates as the $\mathrm{pH}$ increases. These authors, however, have found significant differences between reactions at $\mathrm{pH} 5.5$ and 7.0, which were not observed herein. Processes involving higher concentrations are more influenced by adsorption phenomenon due to the larger amount of precipitates. Indeed, those authors investigated initial concentrations approximately 100 times lower than those employed in the present study.

Overall, results demonstrated that in the absence of other contaminants there is directly proportional relation between the $\mathrm{pH}$ and the efficiency of processes in terms of manganese removal. Under conditions of high redox potential, $\mathrm{Mn}$ (IV) is thermodynamically favourable and predominant in aqueous systems containing manganese. As the Eh decreases slightly other compounds such as $\mathrm{Mn}_{2} \mathrm{O}_{3}$ and $\mathrm{Mn}_{3} \mathrm{O}_{4}$ can be also formed. However, all these phases might also develop even at lower Eh condition providing that the $\mathrm{pH}$ is raised as presented in the Figure 2. Therefore, the improved efficiency, that is, the greater precipitate development observed in higher $\mathrm{pH}$,

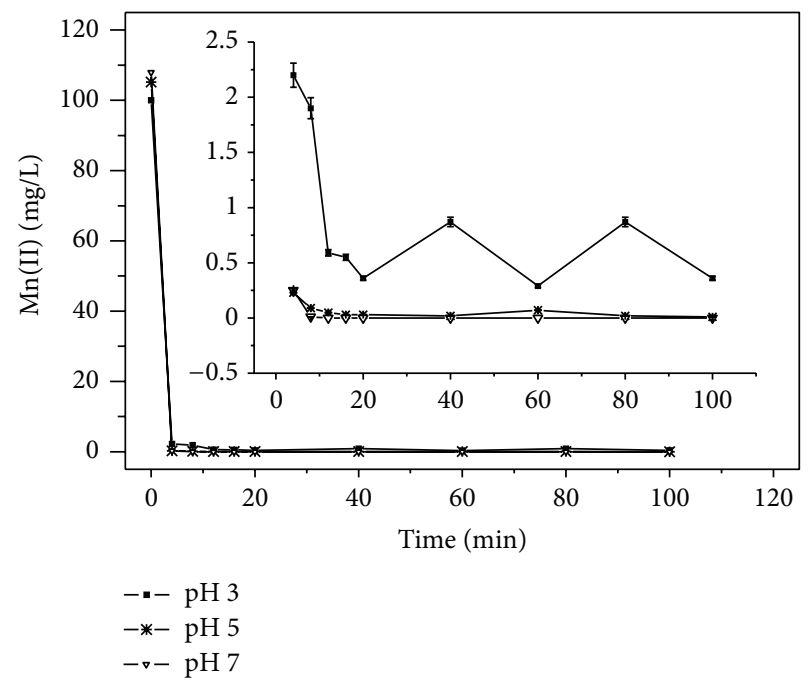

Figure 1: Effect of $\mathrm{pH}$ on manganese removal from laboratory solutions containing initial Mn (II) concentrations about $100 \mathrm{mg} / \mathrm{L}$. Temperature, $25^{\circ} \mathrm{C} \pm 0.5$.

levels was expected and consistent with results found in the literature $[6-8,12]$. Further investigation, however, is needed to identify chemical mechanisms to explain the dependence of the rate of solid-phase formation on $\mathrm{pH}$ of the media.

3.2. Characterization of Acids Effluents. Table 1 presents the chemical composition of both mine waters identified as A1 and $\mathrm{A} 2$ as well as the limits for discharge of effluents set by the Brazilian legislation CONAMA Resolution 430 [4]. Manganese, fluoride, and $\mathrm{pH}$ were outside the established limits [4]. In addition, although the Brazilian legislation does not indicate any restriction, the levels of calcium, aluminium, and sulphate were particularly high compared to concentrations usually found in natural waters. The elevated concentration of these contaminants might result from the typical oxisol present in the mining region, which is extremely weathered and contains high aluminium, calcium, and fluoride levels. These elements are leached from piles of waste rock and tailings, where the generation of AMD takes place. High sulphate is a typical characteristic of AMD, product of the multistep reaction between the pyrite and the oxygen in aqueous media.

3.3. Oxidative Precipitation with $\mathrm{KMnO}_{4}$. Figure 3 shows the variation of manganese contents in the effluents $\mathrm{A} 1$ and $\mathrm{A} 2$ throughout the oxidative precipitation by $\mathrm{KMnO}_{4}$ in bench scale. Similarly to the results obtained for the $\mathrm{MnSO}_{4}$ solutions, not only the reaction rates were higher but also the efficiency improved when the $\mathrm{pH}$ increased, offering a thermodynamically more favourable condition for the development of precipitates as previously described (Item 3.1). For instance, at $\mathrm{pH} 7.0$, in the first 4 min of reaction, $99.7 \%$ and $98.3 \%$ of manganese were removed, respectively, from the effluents $\mathrm{A} 1$ and $\mathrm{A} 2$. While at $\mathrm{pH} 3.0$, removals were 


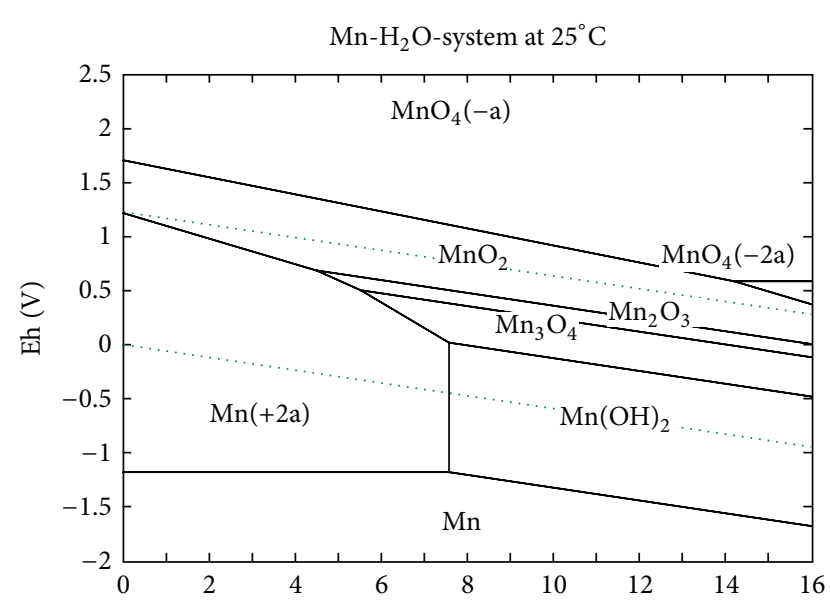

FIGURE 2: Eh-pH diagram showing the predominant manganese forms $\mathrm{Mn}-\mathrm{H}_{2} \mathrm{O}$ systems. Temperature, $25^{\circ} \mathrm{C} \pm 0.5$.

$85.4 \%$ and $96.1 \%$. Based on the established discharge limit of $1.0 \mathrm{mg} / \mathrm{L}$ [4], only processes at $\mathrm{pH} 7.0$ were efficient.

Results also evidenced impacts of the presence of other contaminants in AMD on the overall efficiency of the process. In contrast with experiments conducted with $\mathrm{MnSO}_{4}$ solutions, (Item 3.1), the process was not as much effective when applied for AMD samples. Unexpectedly, removals obtained at $\mathrm{pH} 5.0$ were lower than those obtained at $\mathrm{pH} 3.0$ and 7.0, and significant differences were observed between trials carried out at pH 5.0 and 7.0. Mechanisms by which other elements interfere in the oxidative precipitation by $\mathrm{KMnO}_{4}$ require further investigation. Higher $\mathrm{KMnO}_{4}$ consumption is possibly not the major source of the observed differences. Most of the elements were already in oxidised form, with the exception of the iron, originally found in divalent form, $\mathrm{Fe}^{2+}$ at very low concentration in the AMD samples studied.

On the other hand, adsorption and coprecipitation were reported on the available literature as essential elements on aqueous systems containing manganese [12, 25, 26]. Therefore, these factors may be also important in the scope of this research. It seems reasonable to suggest that the number of available sites for manganese adsorption decreases in the presence of other elements, since this process is neither preferential, nor particularly selective, towards manganese ions [25].

Adsorption also supports manganese removal in $\mathrm{KMnO}_{4}$ ratios lower than the stoichiometric ones, considering the $\mathrm{MnO}_{2}$ formation summarised in (1), that is, $1.92 \mathrm{mg}$ de $\mathrm{KMnO}_{4} / \mathrm{mg}$ de $\mathrm{Mn}$ II $[12,27]$. The amount of $\mathrm{KMnO}_{4}$ used in the present study represents only $85 \%$ of the stoichiometry ratio. Hence, it is inferred that $15 \%$ of soluble $\mathrm{Mn}$ was removed by adsorption on manganese oxides surface instead of oxidative precipitation [25]. In fact, the adsorption of unoxidised manganese (II) also depends on the $\mathrm{pH}$ condition as pointed out by Murray et al. [28].

$$
\begin{aligned}
A= & \pi r^{2} 3 \mathrm{Mn}^{2+}+2 \mathrm{KMnO}_{4}+2 \mathrm{H}_{2} \mathrm{O} \\
& \longrightarrow 5 \mathrm{MnO}_{2(\mathrm{~s})}+2 \mathrm{~K}^{+}+4 \mathrm{H}^{+}
\end{aligned}
$$

Table 2 presents the concentration of other contaminants aluminium, calcium, fluorine, iron, manganese, zinc, and uranium in the effluents $\mathrm{A} 1$ and $\mathrm{A} 2$ at each step of the treatment procedure, that is, correction of the $\mathrm{pH}$ and oxidative precipitation by $\mathrm{KMnO}_{4}$. In fact, the oxidation at $\mathrm{pH} 7.0$ had the advantage of being less subjected to the action of other components such as iron, zinc, and uranium, largely removed during the correction of the $\mathrm{pH}$.

3.4. Characterisation of Solid Samples. As experiments conducted at $\mathrm{pH} 7.0$ effectively removed manganese from AMD and $\mathrm{MnSO}_{4}$ solutions, precipitates produced in these trials were appropriately characterised. Solids were found poorly crystalline and Raman spectroscopy was selected to identify the phases. Figure 4 shows Raman spectra for precipitates (Figures 4(b), 4(c), and 4(d)) and also for a standard synthetic birnessite (Figure 4(a)). Although several points of surfaces were selected, no distinct absorption outlines were detected, indicating homogeneity of samples. By comparing the vibrational modes [29], presented in Figures 4(a) and 4 (b) it is reasonable to assume that processes performed with $\mathrm{MnSO}_{4}$ solution (Figure 4(b)) results mainly in Birnessite $\left(\mathrm{MnO}_{2}\right)$. Lovett [27] reported that the transitions of aqueous systems containing manganese to more oxidising conditions, that is, higher $\mathrm{pH}$ and Eh, facilitate formation of oxides. Among several possibilities (e.g., hausmannite, manganite, and pyrolusite) birnessite and feitknechtite forms are more likely to be formed. Birnessite was also found during the biological treatment of AMD by Tan et al. [21].

In contrast, significant alterations of intensity and possible overlays were verified for precipitates arising from the treatment of A1 and A2 effluents (Figures 4(c) and 4(d)). In Figure 4(c) lower intensity in $574.0 \mathrm{~cm}^{-1}$ and higher in $654.2 \mathrm{~cm}^{-1}$ possibly indicate hausmannite $\left(\mathrm{Mn}_{3} \mathrm{O}_{4}\right)$ [29], while higher intensity around $616.5 \mathrm{~cm}^{-1}$ in Figure $4(\mathrm{~d})$ suggests manganite $(\mathrm{MnOOH})$ [29]. Lower definition and overlays (Figures 4(c) and 4(d)) evidence the impact of the presence of other elements on manganese oxides grid. Distinct structures were also revealed by scanning electron microscopy analysis. Solids formed from effluents (Figures 5(b) and 5(c)) are less porous when compared with precipitates from solution $\mathrm{MnSO}_{4}$ (Figure 5(a)). The presence of other elements filling the structure of manganese oxides was confirmed in microanalysis by electron microprobe associated with EDS detector. Analyses identified other metals, such as aluminium, calcium, zinc, iron, uranium, and rare earths as well as fluoride and oxygen in solids generated during the treatment of the effluents A1 and A2.

3.5. Modeling with PHREEQC. PHREEQC software and the WATEQ4F database were employed to provide an enhanced understanding of the process, given the extensive chemical complexity of AMD effluents. The geochemical model developed included all thermodynamically possible phases and successfully simulated the treatment process. Evaluations focused exclusively on saturation index (SI) and phases were assumed to be formed when SI $\geq 0$ [20]. 
A1

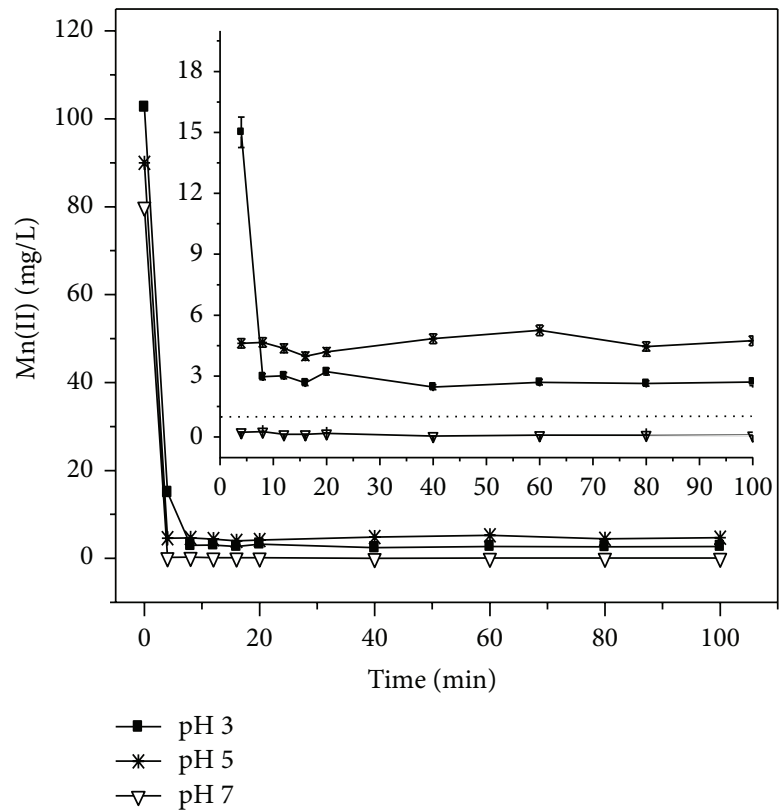

A2

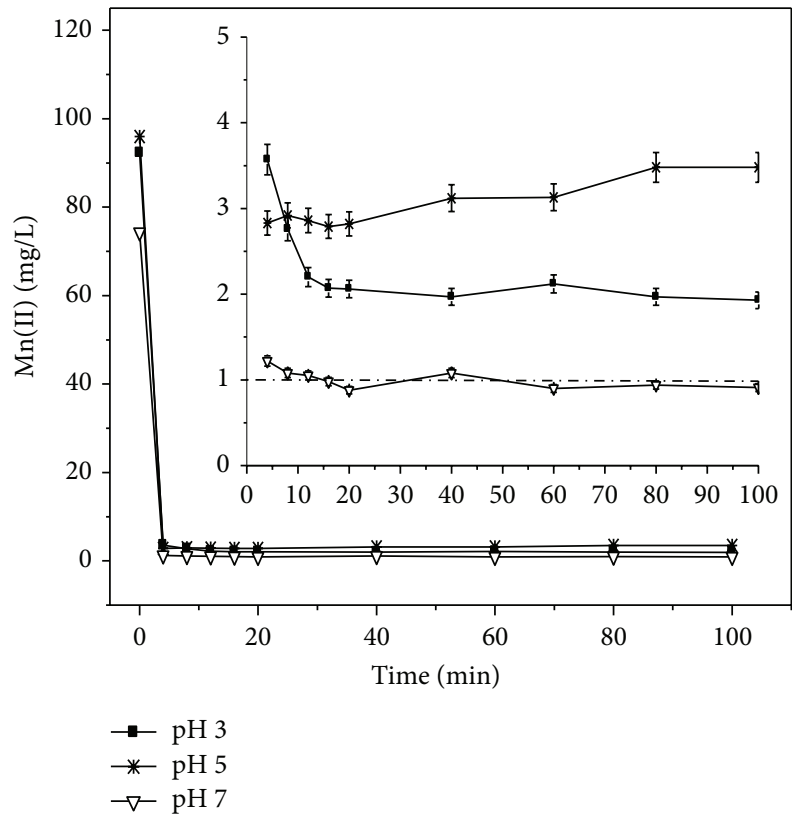

Figure 3: Effect of $\mathrm{pH}$ on the manganese removal with $\mathrm{KMnO}_{4}$ from $\mathrm{AMD}$ effluents, $\mathrm{A} 1$ and $\mathrm{A} 2$. Temperature, $25^{\circ} \mathrm{C} \pm 0.5$. The dotted line represents the limit for manganese discharge (i.e., $1.0 \mathrm{mg} / \mathrm{L}$ ) set by CONANA Resolution 430 [4].

TABLE 2: Removal percentages of chief components from AMD effluents A1 and A2 over $\mathrm{pH}$ adjustment and oxidative precipitation with $\mathrm{KMnO}_{4}$.

\begin{tabular}{|c|c|c|c|c|c|c|c|c|c|c|c|c|}
\hline \multirow{3}{*}{$\begin{array}{l}\text { Stage } \\
\text { Effluent } \\
\mathrm{pH}\end{array}$} & \multicolumn{6}{|c|}{ Removals (\%) at pH adjustment step* } & \multicolumn{6}{|c|}{ Removals (\%) at oxidative precipitation step* } \\
\hline & \multicolumn{3}{|c|}{ A1 } & \multicolumn{3}{|c|}{ A2 } & \multicolumn{3}{|c|}{ A1 } & \multicolumn{3}{|c|}{ A2 } \\
\hline & 3.0 & 5.0 & 7.0 & 3.0 & 5.0 & 7.0 & 3.0 & 5.0 & 7.0 & 3.0 & 5.0 & 7.0 \\
\hline $\mathrm{Al}$ & 1.6 & 16.8 & 83.2 & 6.1 & 41.9 & 97.5 & 10.4 & 52 & 83.2 & 2.3 & 26.2 & 1.7 \\
\hline $\mathrm{Ca}$ & 2.4 & 2.4 & 9.8 & 0.9 & 3.1 & 19.5 & 0 & 12.5 & 14.4 & 20.6 & 17.2 & 5.4 \\
\hline $\mathrm{F}$ & 65.6 & 15.3 & 68.6 & 61.7 & 36.4 & 62.0 & 0 & 56.4 & 8.7 & 25.7 & 0 & 11.1 \\
\hline $\mathrm{Fe}$ & 24.1 & 24.1 & 85.5 & 0 & 100 & 100 & 75.9 & 55.3 & 14.5 & 100 & 0 & 0 \\
\hline $\mathrm{Mn}$ & 0 & 12.3 & 22.3 & 0 & 0 & 19.5 & 97.4 & 83.1 & 77.6 & 97.9 & 96.2 & 79.5 \\
\hline $\mathrm{Zn}$ & 29.3 & 29.4 & 29.5 & 7.1 & 11.2 & 69.6 & 19.8 & 21.8 & 70.5 & 22.4 & 18.3 & 30.4 \\
\hline $\mathrm{U}$ & 29.5 & 24.2 & 29.5 & 26.3 & 21.1 & 21.1 & 17.9 & 23.2 & 17.9 & 0 & 0 & 26.3 \\
\hline
\end{tabular}

${ }^{*}$ Removals percentages are related to initial concentrations presented in Table 1.

Based on simulations during the correction of the $\mathrm{pH}$ possible solid phases formed include $\mathrm{Fe}(\mathrm{OH})_{3}, \mathrm{Fe}_{3}(\mathrm{OH})_{8}$, goethite $(\mathrm{FeOOH})$, hematite and maghemite $\left(\mathrm{Fe}_{2} \mathrm{O}_{3}\right)$, magnetite $\left(\mathrm{Fe}_{3} \mathrm{O}_{4}\right)$, gibbsite $\left(\mathrm{Al}(\mathrm{OH})_{3}\right)$, basaluminite $\left(\mathrm{Al}_{4}(\mathrm{OH})_{10} \mathrm{SO}_{4}\right)$, boehmite and diaspore $(\mathrm{AlOOH})$, jurbanite $\left(\mathrm{AlOHSO}_{4}\right), \mathrm{UO}_{2}(\mathrm{OH})_{2}$ and schoepite $\left(\mathrm{UO}_{2}(\mathrm{OH})_{2} \cdot \mathrm{H}_{2} \mathrm{O}\right)$, hausmannite, manganite, and pyrolusite. Therefore, only iron, uranium, manganese and aluminium would be removed at this stage. Experimentally, however, removal of calcium and zinc was verified, Table 2, whereas removal of both elements was not thermodynamically feasible, and this may be another evidence of adsorption processes.

Addition of $\mathrm{KMnO}_{4}$ was characterised by large removals of calcium and manganese as birnessite, pyrolusite and nsutite $\left(\mathrm{MnO}_{2}\right)$, hausmannite $\left(\mathrm{Mn}_{3} \mathrm{O}_{4}\right)$, bixbyite $\left(\mathrm{Mn}_{2} \mathrm{O}_{3}\right)$, manganite $(\mathrm{MnOOH})$, and fluorite $\left(\mathrm{CaF}_{2}\right)$. The final step simulated the prolonged contact between formed phases and resultant solution. Subsequent to the equilibrium, manganese was found mainly in oxidation state IV as birnessite, pyrolusite, and nsutite $\left(\mathrm{MnO}_{2}\right)$. This result was coherent with those presented by Hem and Lind [30] who studied models to predict the formation of manganese oxides in aqueous systems. According to these authors, in extended contact, the degree of oxidation of manganese increases by the disproportionation of phases, such as manganite and hausmannite.

Overall, it is worth mentioning that speciation-solubility models do not offer temporal and special information; that is, kinetics and distribution parameters were not considered. Therefore, although solid phases were thermodynamically possible, kinetically the development of determined phase might not be favourable. In fact, whether solid phases, for 


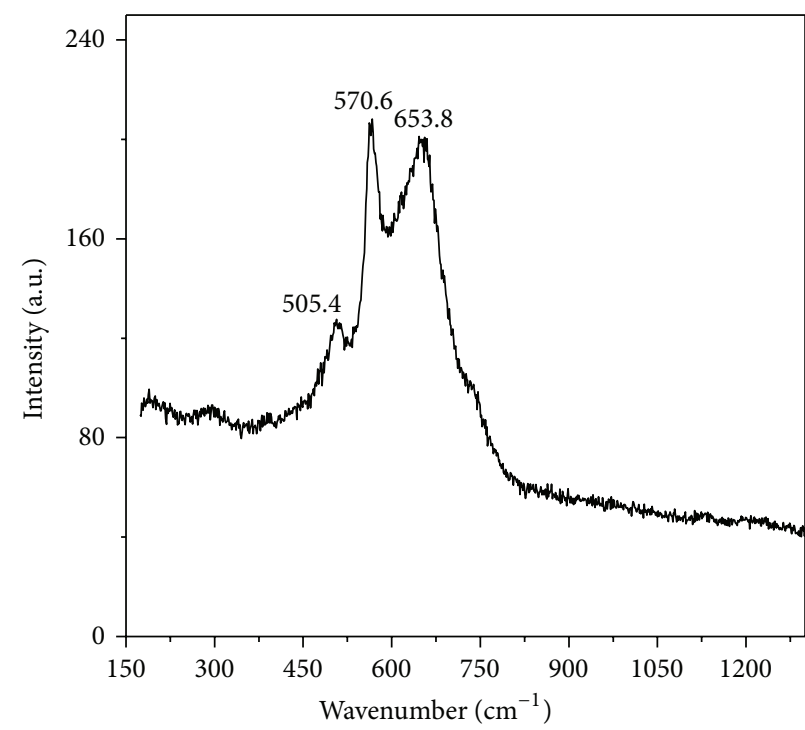

(a)

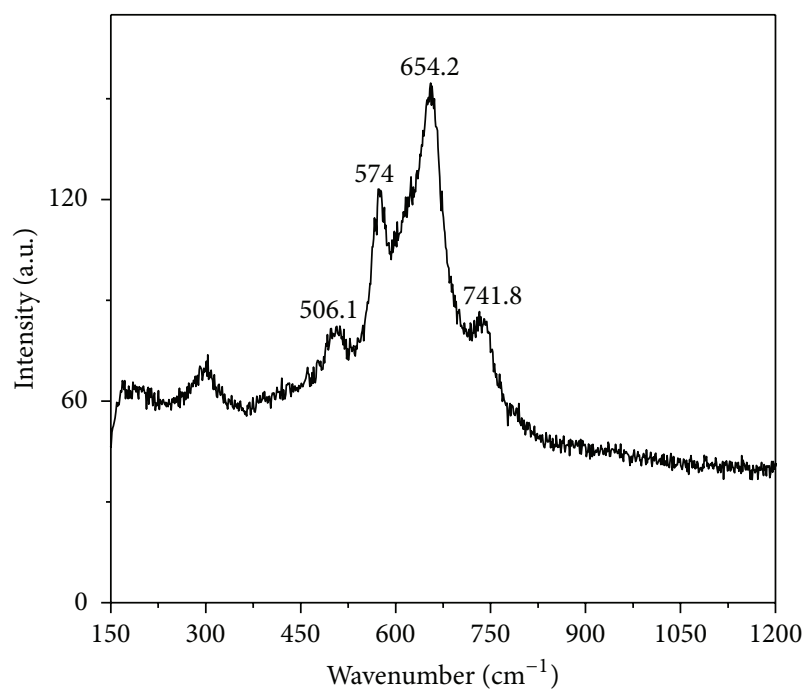

(c)

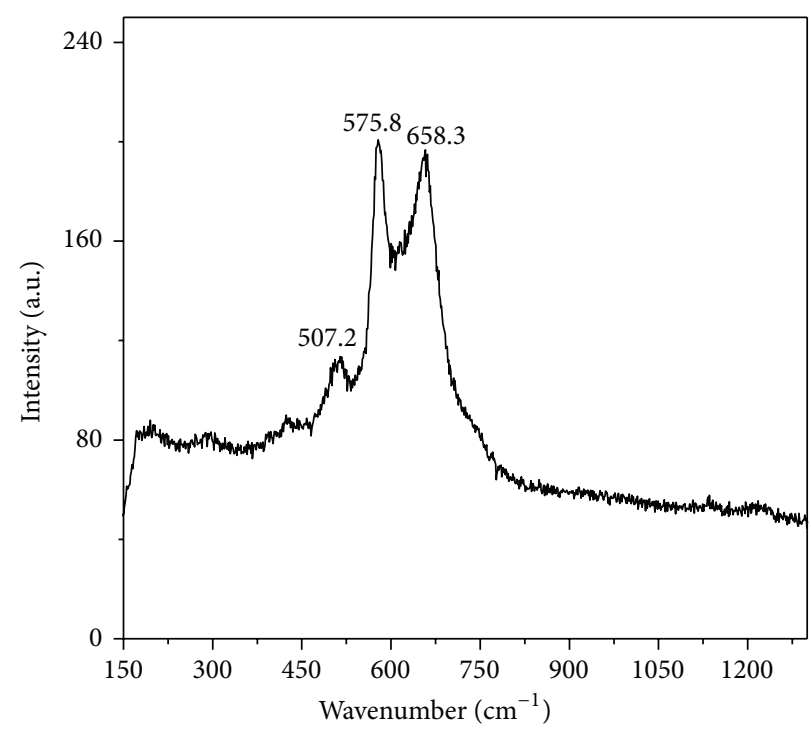

(b)

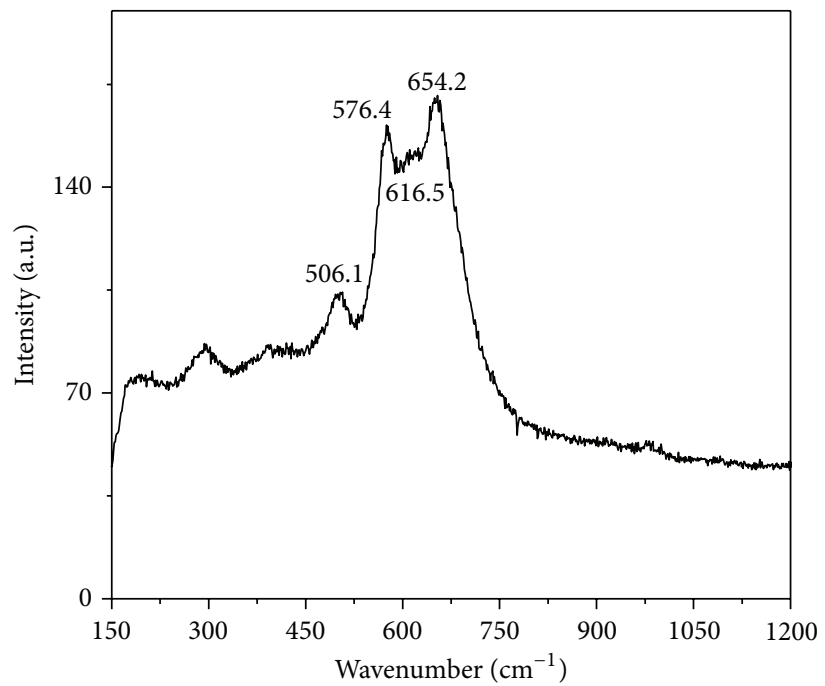

(d)

FIGURE 4: Raman spectra (a) standard synthetic birnessite $\left(\mathrm{MnO}_{2}\right)$; (b) precipitate from $\mathrm{MnSO}_{4}$ solution; (c) precipitate from effluent A1; (d) precipitate from effluent $\mathrm{A} 2$. Trials at $\mathrm{pH} 7.0,25^{\circ} \mathrm{C} \pm 0.5$, and $1 \mathrm{~atm}$.

instance, goethite, $\mathrm{UO}_{2}(\mathrm{OH})_{2}$ and manganite, were actually formed or whether most of metals are incorporated into the manganese oxides phase is difficult to predict.

\section{Conclusions}

Manganese present in highly contaminated AMD was rapidly and effectively oxidised by $\mathrm{KMnO}_{4}$ in a process enhanced at higher $\mathrm{pH}$. At $\mathrm{pH} 7.0$, the process removed $99 \%$ of manganese initially present, meeting the limit established by Brazilian legislation of $1.0 \mathrm{mg} / \mathrm{L}$, within $20 \mathrm{~min}$ of reaction. Results evidenced that adsorption and coprecipitation are important factors in the removal of manganese and other contaminants such calcium and zinc. Consistent with instrumental analyses, the developed geochemical model using PHREEQC code successfully predicted the formation of birnessite $\left(\mathrm{MnO}_{2}\right)$, hausmannite $\left(\mathrm{Mn}_{3} \mathrm{O}_{4}\right)$, and manganite $(\mathrm{MnOOH})$ as well as phases containing aluminium, calcium, iron, and uranium in the precipitates. Overall, although experiments were performed in a bench scale, results obtained support the oxidative precipitation by $\mathrm{KMnO}_{4}$ as a potential treatment for heavily contaminated AMD. However, further investigation remains necessary to clarify chemical mechanisms involved in the control of the oxidation rates of manganese present in highly concentrated solutions as well as the influence of the $\mathrm{pH}$ in this process.

\section{Acknowledgments}

The authors are grateful to the Brazilian agencies CAPES, Fapemig and $\mathrm{CNPq}$ for the financial support. 


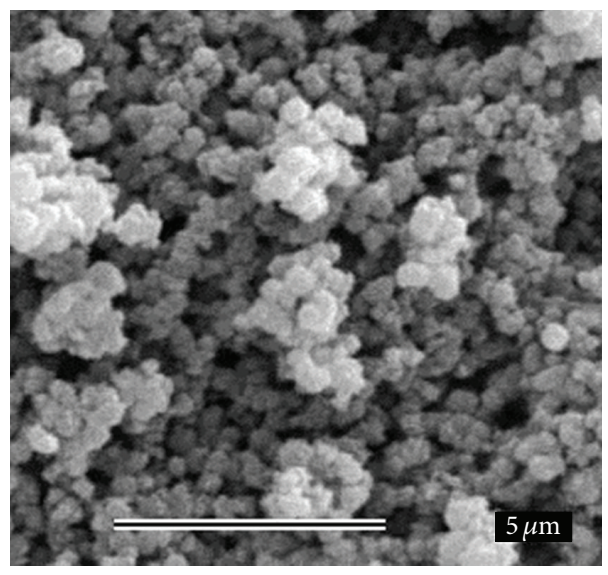

(a)

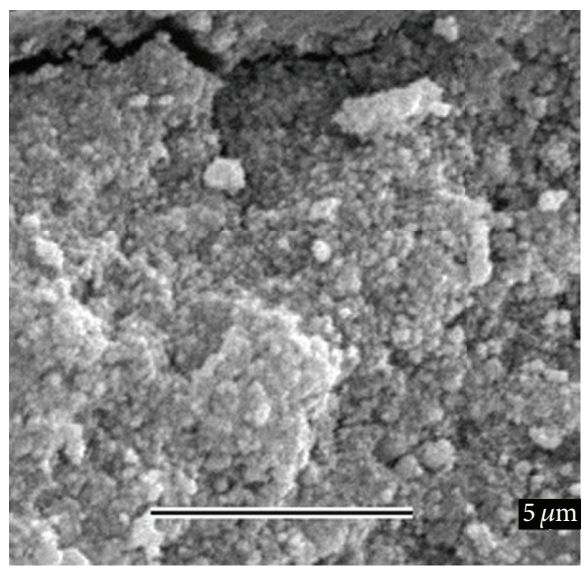

(b)

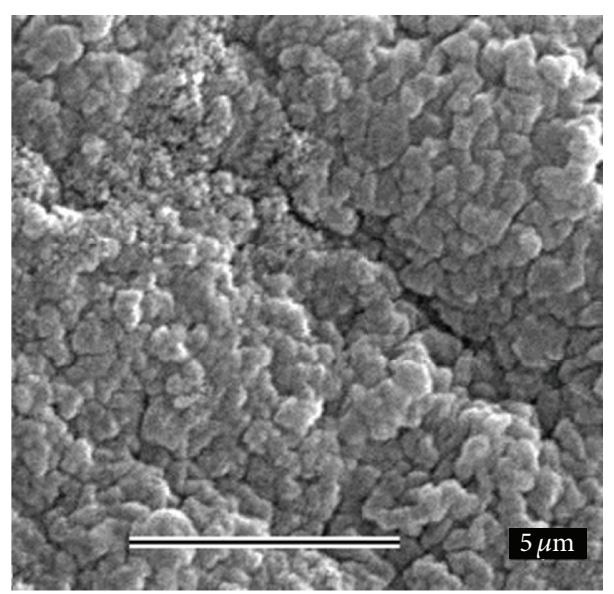

(c)

Figure 5: Micrographs, $8000 \mathrm{X}$, of precipitates obtained by manganese oxidation by $\mathrm{KMnO}_{4}$ at $\mathrm{pH}$ 7.0: (a) $\mathrm{MnSO}_{4}$ solution; (b) effluent A1; (c) effluent A2.

\section{References}

[1] D. B. Johnson, "Chemical and microbiological characteristics of mineral spoils and drainage waters at abandoned coal and metal mines," Water, Air, and Soil Pollution, vol. 3, no. 1, pp. 47-66, 2003.

[2] D. B. Johnson and K. B. Hallberg, "Acid mine drainage remediation options: a review," Science of the Total Environment, vol. 338, no. 1-2, pp. 3-14, 2005.

[3] A. Akcil and S. Koldas, "Acid Mine Drainage (AMD): causes, treatment and case studies," Journal of Cleaner Production, vol. 14, no. 12-13, pp. 1139-1145, 2006.

[4] CONAMA, Conselho Nacional do Meio Ambiente, Resolution 430, Brazil Ministério do Meio Ambiente, MMA, 2011, http:// www.mma.gov.br/port/conama/res/res11/propresol_lanceflue 30e31mar11.pdf.

[5] J. W. Zhu, Z. Zhang, X.-M. Li, X.-H. Xu, and D.-H. Wang, "Manganese removal from the Qiantang River source water by pre-oxidation: a case study," Journal of Zhejiang University A, vol. 10, no. 3, pp. 450-457, 2009.

[6] P. Roccaro, C. Barone, G. Mancini, and F. G. A. Vagliasindi, "Removal of manganese from water supplies intended for human consumption: a case study," Desalination, vol. 210, no. 1-3, pp. 205-214, 2007.
[7] R. Raveendran, B. Ashworth, and B. Chatelier, "Manganese removal in drinking water systems," in Proceedings of the 64th Annual Water Industry Engineers and Operations Conference, pp. 92-100, Bendigo, Australia, 2001.

[8] D. Ellis, C. Bouchard, and G. Lantagne, "Removal of iron and manganese from groundwater by oxidation and microfiltration," Desalination, vol. 130, no. 3, pp. 255-264, 2000.

[9] A. M. Silva, E. C. Cunha, F. D. R. Silva, and V. A. Leão, “Treatment of high-manganese mine water with limestone and sodium carbonate," Journal of Cleaner Production, vol. 29-30, pp. 11-19, 2012.

[10] A. F. S. Gomes, L. L. Lopez, and A. C. Q. Ladeira, "Characterization and assessment of chemical modifications of metal-bearing sludges arising from unsuitable disposal," Journal of Hazardous Materials, vol. 199-200, pp. 418-425, 2012.

[11] W. Zhang and C. Y. Cheng, "Manganese metallurgy review. Part II: manganese separation and recovery from solution," Hydrometallurgy, vol. 89, no. 3-4, pp. 160-177, 2007.

[12] J. E. van Benschoten, W. Lin, and W. R. Knocke, "Kinetic modeling of manganese (II) oxidation by chlorine dioxide and potassium permanganate," Environmental Science and Technology, vol. 26, no. 7, pp. 1327-1333, 1992.

[13] Degrémont, Water Treatment Handbook, Degrémont, Paris, France, 6th edition, 1991. 
[14] O. J. Hao, A. P. Davis, and P. H. Chang, "Kinetics of manganese (II) oxidation with chlorine," Journal of Environmental Engineering, vol. 117, no. 3, pp. 359-375, 1991.

[15] S. J. Tewalt, M. Sato, F. T. Dulong, S. G. Neuzil, A. Kolker, and K. O. Dennen, "Use of ozone to remediate from coal mine drainage waters," in Proceedings of the National Meeting of the American Society of Mining and Reclamation, pp. 19-23, Breckenridge, Colo, USA, 2005.

[16] W. Zhang, P. Singh, and D. M. Muir, "SO2/O2 as an oxidant in hydrometallurgy," Minerals Engineering, vol. 13, no. 13, pp. 13191328, 2000.

[17] C. M. Kao, K. D. Huang, J. Y. Wang, T. Y. Chen, and H. Y. Chien, "Application of potassium permanganate as an oxidant for in situ oxidation of trichloroethylene-contaminated groundwater: a laboratory and kinetics study," Journal of Hazardous Materials, vol. 153, no. 3, pp. 919-927, 2008.

[18] J. Skousen and P. Ziemkiewicz, Acid Mine Drainage Control and Treatment, National Research Center for Coal and Energy, National Mine Land Reclamation Center, Morgantown, Wva, USA, 1996.

[19] M. A. Kessick and J. J. Morgan, "Mechanism of autoxidation of manganese in aqueous solution," Environmental Science and Technology, vol. 9, no. 2, pp. 157-159, 1975.

[20] D. L. Parkhurst and C. A. J. Appelo, "User's guide to PHREEQC (version 2)-a computer program for speciation, batchreaction, one-dimensional transport, and inverse geochemical calculations," U. S. Geological Survey Water-Resources Investigations Report 99-4259, 1999.

[21] H. Tan, G. Zhang, P. J. Heaney, S. M. Webb, and W. D. Burgos, "Characterization of manganese oxide precipitates from Appalachian coal mine drainage treatment systems," Applied Geochemistry, vol. 25, no. 3, pp. 389-399, 2010.

[22] W. M. Gitari, L. F. Petrik, D. L. Key, and C. Okujeni, "Partitioning of major and trace inorganic contaminants in fly ash acid mine drainage derived solid residues," International Journal of Environmental Science and Technology, vol. 7, no. 3, pp. 519-534, 2010.

[23] M. A. Robinson-Lora and R. A. Brennan, "Biosorption of manganese onto chitin and associated proteins during the treatment of mine impacted water," Chemical Engineering Journal, vol. 162, no. 2, pp. 565-572, 2010.

[24] J. W. Ball and D. K. Nordstrom, "WATEQ4F-user's manual with revised thermodynamic data base and test cases for calculating speciation of major, trace and redox elements in natural waters," U. S.Geological Survey Open-File, 1991.

[25] J. E. Post, "Manganese oxide minerals: crystal structures and economic and environmental significance," Proceedings of the National Academy of Sciences of the United States of America, vol. 96, no. 7, pp. 3447-3454, 1999.

[26] K. Lange, R. K. Rowe, and H. Jamieson, "Metal retention in geosynthetic clay liners following permeation by different mining solutions," Geosynthetics International, vol. 14, no. 3, pp. 178-187, 2007.

[27] R. J. Lovett, "Removal of manganese from acid mine drainage," Journal of Environmental Quality, vol. 26, pp. 1017-1024, 1997.

[28] J. W. Murray, J. G. Dillard, R. Giovanoli, H. Moers, and W. Stumm, "Oxidation of $\mathrm{Mn}(\mathrm{II})$ : initial mineralogy, oxidation state and ageing," Geochimica et Cosmochimica Acta, vol. 49, no. 2, pp. 463-470, 1985.

[29] C. M. Julien, M. Massot, and C. Poinsignon, "Lattice vibrations of manganese oxides: part I. Periodic structures," Spectrochimica Acta A, vol. 60, no. 3, pp. 689-700, 2004.
[30] J. D. Hem and C. J. Lind, "Nonequilibrium models for predicting forms of precipitated manganese oxides," Geochimica et Cosmochimica Acta, vol. 47, no. 11, pp. 2037-2046, 1983. 

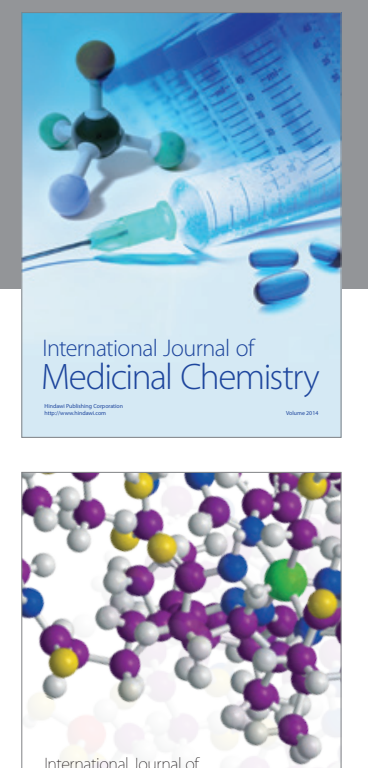

\section{Carbohydrate} Chemistry

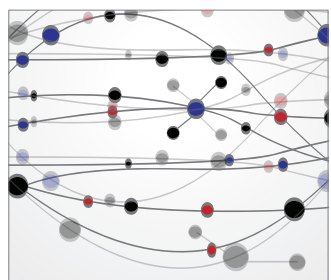

The Scientific World Journal
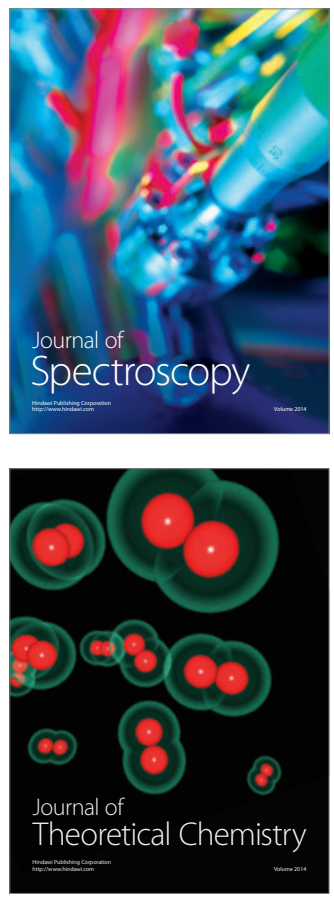
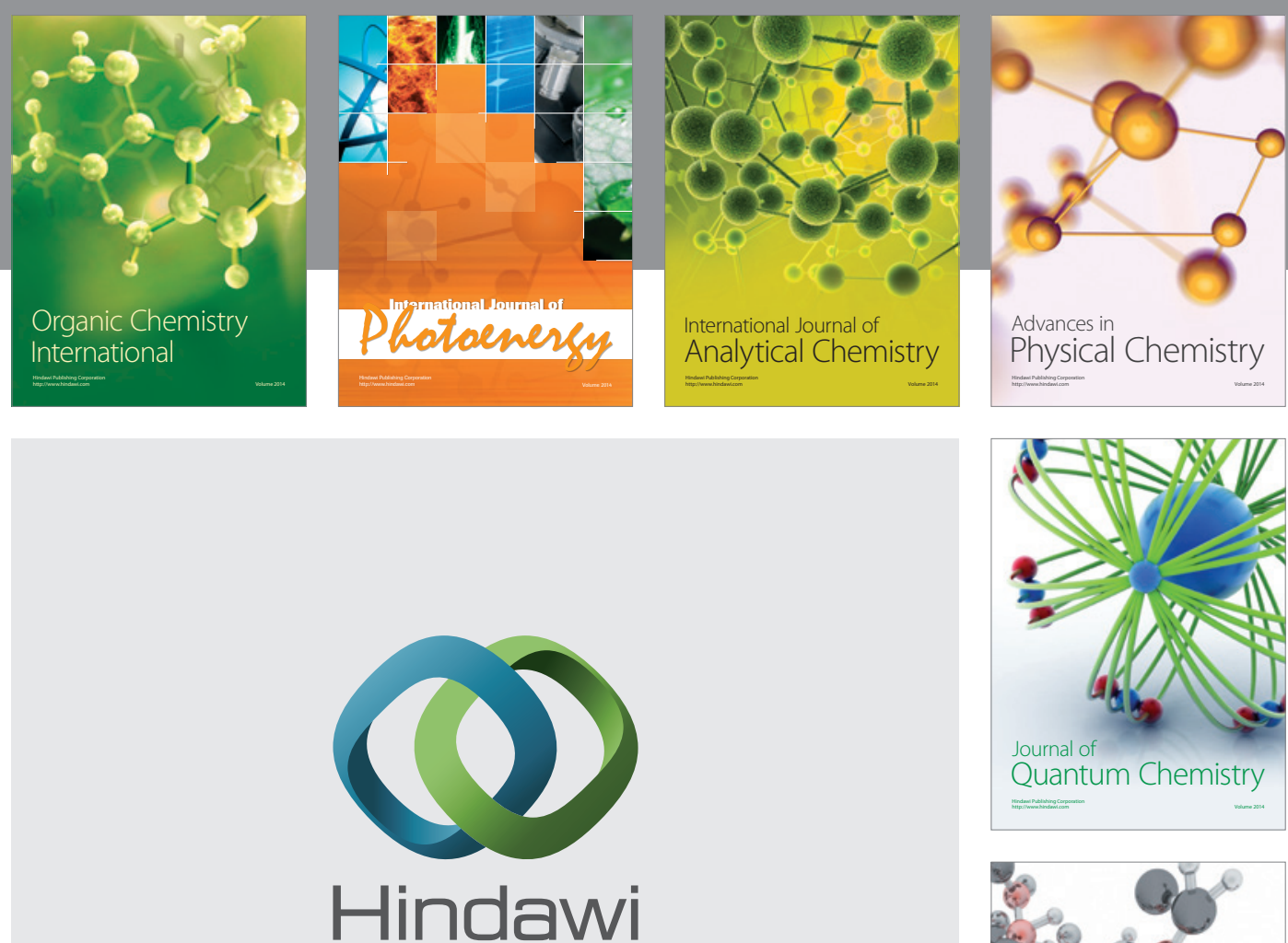

Submit your manuscripts at

http://www.hindawi.com

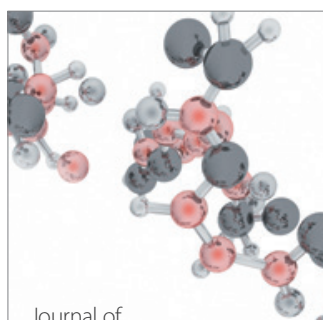

Analytical Methods

in Chemistry

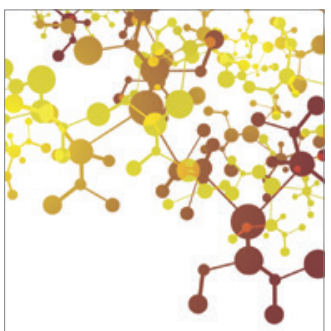

Journal of

Applied Chemistry

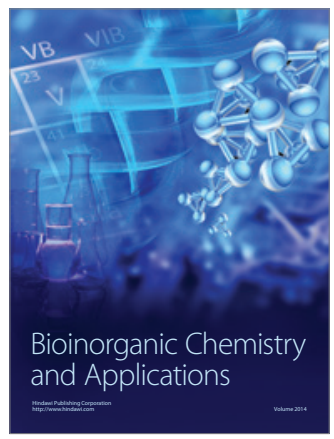

Inorganic Chemistry
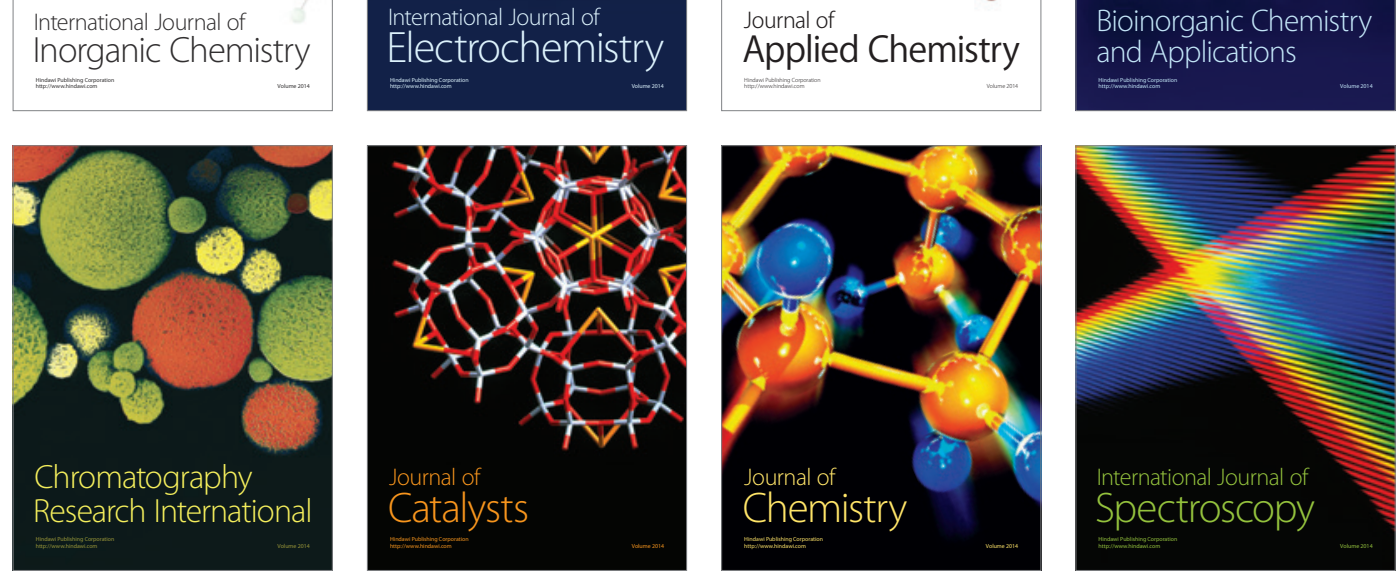